JDHT Journal of Dental Hygiene and Therapy

Volume1, Nomor 1 Tahun 2020

eISSN : xxxx-xxxx, DOI: xx.xxxxx/jdht.vxix.xx

\title{
LESI GINGIVA PADA PASIEN PENGGUNA GIGI TIRUAN SEBAGIAN \\ LEPASAN DI KLINIK DW 8 DENTAL CARE PERIODE BULAN JANUARI-MARET TAHUN 2020
}

\author{
Dwi Priharti $^{1}$, Emini ${ }^{1}$, Nita Noviani ${ }^{1}$, Syifa Yulia Lestari ${ }^{1}$, Nuranidah ${ }^{2}$ \\ ${ }^{1}$ Jurusan Keperawatan Gigi, Politeknik Kesehatan Kemenkes Jakarta I, Indonesia \\ ${ }^{2}$ Klinik DW 8 Dental Care Jakarta Selatan, Indonesia
}

\begin{tabular}{ll}
\hline Info Artikel & Abstrak \\
\hline Genesis Naskah: & $\begin{array}{l}\text { Latar Belakang: Gigi tiruan sebagian lepasan (GTSL) adalah gigi tiruan yang menggantikan satu } \\
\text { atau beberapa gigi yang hilang pada rahang atas atau rahang bawah dan dapat dibuka pasang }\end{array}$ \\
Submitted: 3 April 2020 & oleh pasien. Perawatan dengan gigi tiruan sebagian lepasan adalah perawatan yang dapat dipilih \\
Revised: 11 April 2020 & untuk merestorasi kehilangan gigi oleh sebagian besar pasien yang kehilangan gigi sebagian \\
Accepted:26 April 2020 & karena biayanya yang lebih terjangkau. Gigi tiruan sebagian lepasan dapat menyebabkan trauma \\
& pada jaringan keras maupun lunak di bawah gigi tiruan. Tujuan: Tujuan penelitian ini adalah \\
& untuk mengetahui lesi gingiva pada pasien pengguna gigi tiruan sebagian lepasan di klinik DW 8 \\
& Dental Care periode bulan Januari s/d Maret tahun 2020. Metode: Penelitian ini menggunakan \\
& metode deskriptif dengan sampel penelitian menggunakan teknik total sampling sebanyak 44 \\
& responden. Data yang digunakan yaitu data sekunder yang diambil dari rekam medis pasien. \\
Kata Kunci: & Hasil: Hasil penelitian diperoleh jenis gigi tiruan sebagain lepasan yang digunakan pasien \\
Lesi gingiva, gigi tiruan & diklinik DW 8 Dental Care adalah akrilik (61,4\%) dan valplast (38,6\%). Lesi gingiva yang \\
sebagian lepasan & terjadi pasien pengguna gigi tiruan sebagai lepasan yaitu gingivitis (36,4\%) dan stomatitis \\
& (27,2\%). Kesimpulan: Sebagian besar pasien gigi tiruan diklinik DW 8 Dental Care adalah \\
& akrilik dan mengalami stomatitis.
\end{tabular}

GINGIVA LESION IN PATIENT USERS OF PARTIAL DENTAL IN CLINIC DW 8 DENTAL CARE PERIOD OF MONTHS JANUARY-MARCH 2020

\begin{tabular}{|c|c|}
\hline Keywords: & Abstract \\
\hline $\begin{array}{l}\text { Gingival lesions, removable } \\
\text { partial dentures }\end{array}$ & $\begin{array}{l}\text { Background: Removable partial dentures (GTSL) are artificial teeth that replace one or several } \\
\text { missing teeth in the upper jaw or lower jaw and can be opened by the patient. Treatment with } \\
\text { removable partial dentures is a treatment that can be chosen to restore tooth loss by the } \\
\text { majority of patients who have lost partial teeth because the costs are more affordable. } \\
\text { Removable partial dentures can cause trauma to the hard or soft tissue under the denture. } \\
\text { Objective: The purpose of this study was to determine of gingival lesions in patients using } \\
\text { removable partial dentures in the DW } 8 \text { Dental Care clinic from January to March } 2020 . \\
\text { Methods: This study used a descriptive method with a sample of research using a total sampling } \\
\text { technique of } 44 \text { respondent. The data used are secondary data taken from the patient's medical } \\
\text { record. Results: The results of this study showed that the type of denture removable patients } \\
\text { used in the DW } 8 \text { Dental Care clinic were acrylic (61.4\%) and valplast (38.6\%). Gingival } \\
\text { lesions that occur in patients using dentures as removable are gingivitis (36.4\%) and stomatitis } \\
\text { (27.2\%). Conclusion: Most denture patients in the DW } 8 \text { Dental Care clinic are acrylic and have } \\
\text { stomatitis. }\end{array}$ \\
\hline
\end{tabular}

\section{Korespondensi Penulis:}

Syifa Yulia Lestari

Jl. Wijaya Kusuma No. 47-48 Cilandak, Jakarta Selatan, Indonesia

Email: syifa_yulia95@yahoo.co.id

(C) Jurusan Keperawatan Gigi Poltekkes Kemenkes Jakarta I

Jl. Wijaya Kusuma No. 47-48 Cilandak Jakarta Selatan, Indonesia

email: jdht@poltekkesjakarta1.ac.id 


\section{Pendahuluan}

Undang-Undang Nomor 36 Tahun 2009 tentang Kesehatan pasal 93 dan 94, dinyatakan bahwa pelayanan kesehatan gigi dan mulut dilakukan untuk memelihara dan meningkatkan derajat kesehatan masyarakat dalam bentuk peningkatan kesehatan gigi, pencegahan penyakit gigi, pengobatan penyakit gigi, dan pemulihan kesehatan gigi yang dilakukan secara terpadu, terintegrasi dan berkesinambungan (Kemenkes RI, 2012). Pelayanan kesehatan gigi dilaksanakan melalui perseorangan, pelayanan kesehatan gigi masyarakat, usaha kesehatan gigi sekolah, serta pemerintah dan pemerintah daerah wajib menjamin ketersediaan tenaga, fasilitas pelayanan, alat dan obat kesehatan gigi dan mulut dalam rangka memberikan pelayanan kesehatan gigi dan mulut yang aman, bermutu, dan terjangkau oleh masyarakat (Kemenkes RI, 2012).

Penyakit gigi dan mulut menduduki peringkat pertama yaitu meliputi $60 \%$ penduduk dimana penyakit periodontal merupakan penyebab utama terjadinya kehilangan gigi (Khoman dkk, 2012). Berdasarkan Survei Nasional Riskesdas 2018 melaporkan sebesar $57,8 \%$ penduduk Indonesia mengalami masalah kesehatan gigi; dengan index DMF-T pada usia 15 tahun sebesar 2,40 dan usia 3544 tahun sebesar 7,02 artinya rata-rata jumlah karies gigi sebesar 2 sampai 7 gigi setiap orang (Riskesdas, 2018).

Kehilangan gigi bisa dialami oleh siapa saja tanpa memandang usia ataupun jenis kelamin. Kehilangan gigi bisa disebabkan karena alasan fisiologis ataupun kehilangan yang diakibatkan buruknya status kesehatan gigi terutama oleh karena penyakit periodontal, trauma, karies. Penyebab lainnya diakibatkan oleh kegagalan perawatan sebelumnya, serta kelainan atau gangguan pertumbuhan (Jayanti dan Pintadi, 2016). Kehilangan gigi dapat menyebabkan terganggunya ketiga fungsi tersebut, sehingga menyebabkan menurunnya kualitas hidup seseorang akibat dari berkurangnya kemampuan mengunyah makanan, turunnya status kepercayaan diri, hingga terganggunya kemampuan dalam berbicara (Lahama dkk, 2015).

(C) Jurusan Keperawatan Gigi Poltekkes Kemenkes Jakarta I Jl. Wijaya Kusuma No. 47-48 Cilandak Jakarta Selatan, Indonesia email: jdht@poltekkesjakarta1.ac.id
Hasil survei pemakaian gigi tiruan di beberapa negara termasuk Indonesia masih rendah. Di Indonesia sendiri berdasarkan hasil survei tahun 2007 menunjukkan hanya 4,5\% dari penduduk Indonesia yang menggunakan gigi tiruan. Di Cina prevalensi penggunaan gigi tiruan pada manula hanya sebesar 38,7\%. Di Jepang tahun 2002 prevalensi penggunaan gigi tiruan hanya mencapai $30 \%$ dari penduduk Jepang (Khoman dkk, 2013).

Gigi tiruan digunakan untuk mengantikan gigi yang hilang dan mengembalikan estetika serta kondisi fungsional pasien. Gigi tiruan yang biasanya disebut protesa bisa dalam bentuk gigi tiruan cekat (fixed) atau gigi tiruan lepasan (removable) (Jayanti dan Pintadi, 2016). Gigi tiruan sebagian lepasan (GTSL) adalah gigi tiruan yang menggantikan satu atau beberapa gigi yang hilang pada rahang atas atau rahang bawah dan dapat dibuka pasang oleh pasien. Perawatan dengan gigi tiruan sebagian lepasan adalah perawatan yang dapat dipilih untuk merestorasi kehilangan gigi oleh sebagian besar pasien yang kehilangan gigi sebagian karena biayanya yang lebih terjangkau (Lenggogeny dkk, 2015).

Pengguna gigi tiruan lepasan harus memperhatikan kebersihan gigi tiruannya untuk mencegah kehilangan gigi lebih lanjut, terjadinya peradangan pada jaringan mukosa di bawah gigi tiruan, terbentuknya plak pada basis gigi tiruan, gigi tiruan berbau, serta berkembangnya mikroorganisme seperti jamur candida albicans yang dapat menyebabkan terjadinya denture stomatitis (Muluwere dkk., 2015). Seorang yang mengalami kehilangan gigi akan menyebabkan ketidakseimbangan sistem mastikasi. Seorang yang mengalami kehilangan gigi cenderung akan menggunakan sisi yang memiliki gigi dibandingkan dengan sisi yang tidak memilki gigi untuk pengunyahan karena otak akan memerintahkan untuk menghindari bagian tersebut (Jayanti dan Pintadi, 2016).

Gigi tiruan sebagian lepasan dapat menyebabkan trauma pada jaringan keras maupun lunak di bawah gigi tiruan. Penelitian Watuna dkk (2015) menunjukan bahwa adanya ulser akibat gigi tiruan dengan sebagian besar pada jaringan lunak 
rongga mulut yang menggunakan gigi tiruan sebagian lepasan pembengkakan gingiva $30 \%$ dan denture stomatitis $50 \%$.

Data laporan Klinik DW 8 Dental Care tahun 2019 menunjukkan pasien dengan kasus gigi palsu sebanyak 425 pasien, terdiri dari gigi tiruan lepasan sebagian sebanyak 225 dan gigi tiruan cekat 200 pasien.

Berdasarkan permalahan di atas penulis tertarik untuk melakukan penelitian dengan judul "Lesi gingiva pada pasien pengguna gigi tiruan sebagian lepasan di klinik DW 8 Dental Care periode bulan Januari-Maret tahun 2020"

\section{Metode}

Desain penelitian yang digunakan adalah penelitian deskriptif. Penelitian ini menggunakan data sekunder yang diambil dari rekam medik kemudian dicatat menggunakan lembar rekapitulasi yang telah ditentukan oleh peneliti. Data yang telah di kumpulkan akan dianalisa menggunakan perhitungan statistik deskriptif berupa angka dan persentasi. Analisa data dilakukan secara manual dan hasil analisa data akan disajikan dalam bentuk tabel. Penelitian ini dimaksudkan untuk melihat gambaran lesi gingiva pada pasien pengguna gigi tiruan sebagian lepasan di klinik DW 8 Dental Care periode bulan Januari-Maret tahun 2020. Sampel dalam penelitian ini menggunakan total sampling di mana seluruh populasi menjadi sampel, maka sampel dalam penelitian ini adalah 44 orang.

\section{Hasil}

Hasil pengumpulan data lesi gingiva pada pasien pengguna gigi tiruan sebagian lepasan di klinik DW 8 Dental Care periode bulan januari-maret tahun 2020, sebagai berikut :

Tabel 1. Distribusi frekuensi jenis gigi tiruan sebagian lepasan

\begin{tabular}{clcc}
\hline No & Jenis GTSL & $\begin{array}{c}\text { Jumlah } \\
\text { Responden }\end{array}$ & Persentase (\%) \\
\hline 1 & Akrilik & 27 & 61,4 \\
2 & Valplast & 17 & 38,6 \\
\hline & Jumlah & 44 & 100 \\
\hline
\end{tabular}

(c) Jurusan Keperawatan Gigi Poltekkes Kemenkes Jakarta I Jl. Wijaya Kusuma No. 47-48 Cilandak Jakarta Selatan, Indonesia email: jdht@poltekkesjakarta1.ac.id
Tabel 1 menunjukkan bahwa responden yang menggunakan jenis gigi tiruan akrilik sebanyak 27 orang $(61,4 \%)$, dan gigi tiruan jenis valplast sebanyak 17 orang $(38,6 \%)$.

Tabel 2. Distribusi frekuensi lesi gingiva pada pengguna gigi tiruan sebagian lepasan

\begin{tabular}{llcc}
\hline No & Lesi Gingiva & $\begin{array}{c}\text { Jumlah } \\
\text { Responden }\end{array}$ & $\begin{array}{c}\text { Persentase } \\
(\%)\end{array}$ \\
\hline 1 & Stomatitis & 12 & 27,2 \\
2 & Gingivitis & 16 & 36,4 \\
3 & Tidak terdapat lesi & 16 & 36,4 \\
\hline & Jumlah & 44 & 100 \\
\hline
\end{tabular}

Tabel 2 menunjukkan bahwa responden yang lesi gingiva berupa stomatitis sebanyak 12 orang $(27,2 \%)$, gingivitis sebanyak 16 orang $(36,4 \%)$, dan responden yang tidak terdapat lesi gingiva sebanyak 16 orang $(36,4 \%)$.

Tabel 3. Lesi gingiva berdasarkan jenis gigi tiruan sebagian lepasan

\begin{tabular}{llcccc}
\hline \multirow{2}{*}{ No } & \multirow{2}{*}{ Lesi Gingiva } & \multicolumn{3}{c}{ Jenis GTSL } \\
\cline { 3 - 6 } & & \multicolumn{2}{c}{ Akrilik } & \multicolumn{2}{c}{ Valplash } \\
\cline { 3 - 6 } & & $\mathrm{f}$ & $\%$ & $\mathrm{f}$ & $\%$ \\
\hline 1 & Stomatitis & 12 & 27,3 & 0 & 0 \\
2 & Gingivitis & 6 & 13,6 & 10 & 22,7 \\
3 & Tidak terdapat & 9 & 20,5 & 7 & 15,9 \\
& lesi & & & & \\
\hline & Jumlah & 27 & 61,4 & 17 & 38,6 \\
\hline
\end{tabular}

Tabel 3 menunjukkan bahwa responden yang lesi gingiva berupa stomatitis pada pengguna akrilik sebanyak 12 orang $(27,3 \%)$ sedangkan tidak terdapat stomatitis pada pengguna vaplash. Untuk responden gingivitis pada pengguna akrilik sebanyak 6 orang $(13,6 \%)$ sedangkan pengguna valplash sebanyak 10 orang $(22,7 \%)$. Responden yang tidak terdapat lesi gingiva yang pengguna akrilik sebanyak 9 orang $(20,5 \%)$ dan responden yang tidak terdapat lesi gingiva yang pengguna valplash sebanyak 7 orang $(15,5 \%)$.

\section{Pembahasan}

Penelitian mengenai gambaran lesi gingiva pada pasien pengguna gigi tiruan sebagian lepasan di klinik DW 8 Dental Care periode bulan Januari s/d Maret tahun 2020. Pelaksanaan peneliltian dilakukan 
pada tanggal 6 Mei 2020 dengan jumlah sampel 44 orang.

Hasil penelitian jenis gigi tiruan sebagain lepasan diperoleh yang menggunakan jenis gigi tiruan akrilik sebanyak 27 orang $(61,4 \%)$ dan valplast sebanyak 17 orang $(38,6 \%)$. Temuan penelitian ini mendukung penyataan Sharma (2014) kebutuhan akan pembuatan gigi tiruan tetap dan gigi tiruan lepasan akan benar-benar meningkat. Faktanya bahwa orang dewasa untuk mempertahankan mereka memiliki proporsi yang lebih besar akan kehilangan gigi sebagian dan juga dan juga memerlukan gigi tiruan lepasan sebagian (GTSL). Banyak pasien memilih GTSL karena faktor biaya. Bahan yang biasa digunakan untuk membuat basis gigi tiruan lepasan yaitu polimetilmetakrilat yang lazim disebut resin akrilik. Bahan akrilik merupakan campuran bahan sejenis plastik, yang manipulasinya mudah, murah, ringan dan bisa diwarnai sesuai dengan warna gigi dan gusi.

Hasil penelitian gambaran lesi gingiva pada pengguna gigi tiruan sebagian lepasan menunjukkan bahwa yang lesi gingiva berupa stomatitis $27,2 \%$, gingivitis $36,4 \%$, dan tidak terdapat lesi gingiva $36,4 \%$, artinya sebagain besar pasien pengguna gigi tiruan sebagai lepasan pernah memiliki lesi gingiva. Hal ini dikarenakan pada pengguna GTSL adalah bagian sayap dari GTSL. Didukung juga dengan pendapat Langkir dkk (2015) lesi traumatik pada pengguna gigi tiruan biasanya terjadi karena adanya tekanan dari dasar atau sayap gigi tiruan bagian lingual, palatinal maupun bukal yang tidak pas atau dari kerangka gigi tiruan sebagian. Sesuai juga penelitian relevan Watuna dkk (2015) menunjukkan sebagian besar pada jaringan lunak rongga mulut yang menggunakan gigi tiruan sebagian lepasan pembengkakan gingiva $30 \%$ dan denture stomatitis $50 \%$.

Denture stomatitis terjadi oleh karena pemakaian gigi tiruan yang terus-menerus sepanjang siang dan malam hari, biasanya juga disebabkan oleh spesies candida yang adalah penghuni umum rongga mulut. Denture Stomatitis ini lebih cenderung terjadi pada rahang atas dari pada rahang bawah pada pengguna gigi tiruan (Isabora, 2012). Berbeda dengan kejadian gingivitis pada pengguna gigi tiruan disebabkan karena penumpukan plak pada sekeliling gigi asli pada gigi tiruan dapat menyebabkan gingivitis. Tetapi jika perawatan mulut dilaksanakan dengan baik dan gigi tiruan dibuat dengan berpegang teguh pada prinsip-prinsip desain, setelah jangka waktu pemakaian dua tahun, hanya sedikit saja kerusakan jaringan timbul (Watuna dkk, 2015).

Hasil penelitian gambaran lesi gingiva pada berdasarkan jenis gigi tiruan sebagian lepasan menunjukkan bahwa didominasi oleh lesi gingiva berupa stomatitis pada pengguna gigi tiruan jenis akrilik. Hal ini disebabkan akrilik mempunyai sayap yang menekan tulang alveolaris dan penyangga gigi lainnya serta proses pembersihan gigi yang kurang optimal. Berbeda dengan gigi tiruan jenis valplast jarang terjadi stomatitis, karena valplast memiliki kelebihan diantaranya adalah bahanya lebih elastis dan tipis serta mampu menyesuaikan dengan gusi sehingga tidak menekan gusi yang menyebakan stomatitis. Diperkuat Gunadi dkk (2012) menyatakan gigi tiruan sebagian lepasan jenis valplast memiliki tingkat kelenturan sangat baik dan mampu beradaptasi dengan gusi.

\section{Kesimpulan}

Hasil penelitian gambaran lesi gingiva pada pasien pengguna gigi tiruan sebagian lepasan di klinik DW 8 Dental Care periode bulan Januari-Maret tahun 2020, dapat menyimpulkan sebagai berikut:

1. Didapatkan jenis gigi tiruan sebagain lepasan yang digunakan adalah akrilik $(61,4 \%)$ dan valplast $(38,6 \%)$.

2. Didapatkan sebagain besar pasien pengguna gigi tiruan sebagai lepasan mengalami lesi gingiva berupa gingivitis $(36,4 \%)$ dan stomatitis $(27,2 \%)$ serta sebagian besar pengguna gigi tiruan jenis akrilik mengalami stomatitis.

Berdasarkan hasil penelitian ini, saran yang dapat peneliti berikan diantara sebagai berikut:

1. Memberikan masukan kepada klinik DW 8 Dental Care agar dilakukan peningkatan pelayanan kesehatan gigi dan mulut terutama bagi para pengguna gigi tiruan serta melakukan penyuluhan 
tentang pentingnya dan cara merawat kebersihan gigi dan mulut terutama pada pengguna GTSL.

2. Untuk pengguna gigi tiruan sebagian lepasan, diharapkan bagi yang memiliki stomatitis dan gingivitis agar dapat mencegahnya dengan memperbanyak minum vitamin $\mathrm{C}$.

3. Untuk peneliti lain diharapkan dapat dilakukan penelitian dengan variabel yang berbeda dan dengan model pendekatan yang berbeda.

\section{Daftar Pustaka}

Adhiatmitha EK, Fiora RP, Desak N. AS (2018). Faktor-faktor yang berkaitan dengan tingkat perilaku pemeliharaan kebersihan gigi tiruan lepasan akrilik pada lansia di Desa Penatahan Kabupaten Tabanan Bali. Bali Dental Jurnal: Volume 2, Nomor 1, Januari - Juni 2018: 17-23 e-ISSN: 2549-0109.

Gunadi H, Margo A, Burhan L, Suryatenggara F, Setiabudi I (2012). Buku Ajar Ilmu Geligi Tiruan Sebagian Lepasan. Jakarta: Hipokrates.

Ha JS, Lee HC, Cho HJ (2013). Periodontal prosthesis on medically compromised patient with few remaining teeth: hybrid telescopic double crown with friction pin method. Case Report. Kyoungpook National University Daegu Republic of Korea.

Isabora B (2012). Kebiasaan Memelihara Kebersihan Gigi Tiruan Pada Masyarakat Pemakai Gigi Tiruan Sebagian Lepasan Di Kelurahan Tanjung Rejo Kecamatan Medan Sunggal. Skripsi. Medan: Sumatera Univeritas.

Jayanti, Eka Shientia, Hastoro P (2016). Gambaran Status Kebersihan Gigi dan Mulut pada Pasien Prapengguna Gigi Tiruan Cekat Berdasarkan Jenis Kelamin (Kajian di RSGM UMY). Naskah Publikasi. Program Studi Pendidikan Dokter Gigi FKIK Universitas Muhammadiyah Yogyakarta.

Kaomongkolgit R, Wongviriya A, Daroonpan P, Ronnayut C, Weeraya T, Jadesada P (2017). Denture Stomatitis and its Predisposing Factors in Denture Wearers. Journal of International Dental and Medical Research: Volume 10 Number 12017.
Kementerian Kesehatan Republik Indonesia (2018). Riset Kesehatan Dasar. Jakarta: Badan Penelitian dan Pengembangan.

Khoman AJ, Mariati WN, Ellys DS (2012). Profil Pemakaian Gigi Tiruan Lepasan Berbasis Akrilik Pada Masyarakat Kelurahan Bahu Kecamatan Malalayang. Jurnal Biomedik: Volume 4, Nomor 1, Maret 2012, hlm. 43-51.

Lahama L, Wowor VNS, Waworuntu OA (2015). Angka Kejadian Stomatitis Yang Diduga Sebagai Denture Stomatitis Pada Pengguna Gigi Tiruan Di Kelurahan Batu Kota Manado. Pharmacon Jurnal Ilmiah Farmasi. 2015;4:7181.

Muluwere O. Vlorenzy, Ni Wayan Mariati, Dinar A. Wicaksono (2015). Gambaran Pengetahuan Dan Status Kebersihan Mulut Pada Pemakai Gigi Tiruan Sebagai Lepasan Di Kelurahan Batu Kota Kecamatan Malalayang. Jurnal eGiGi $(e G)$ : Volume 3, Nomor 1, Januari-Juni 2015.

Watuna P, Wowor, Siagian (2015). Gambaran Rongga Mulut Pada Lansia Pemakai Gigi Tiruan Sebagian Lepasan Di Panti Werda Kabupaten Minahasa. Jurnal e-GiGi $(e G)$ : Volume 3, Nomor 1, Januari-Juni 2015. 